\title{
Leishmaniasis in dogs from recycling centers and from a neighborhood with adjacent forest in an urban area of Londrina, Paraná, Brazil
}

\section{Leishmaniose em cães de centros de reciclagem e de um bairro nas adjacências de uma mata urbana em Londrina, PR, Brasil}

\author{
Letícia da Costa $^{1}$, Eloiza Teles Caldart ${ }^{1}$; Bruno Bergamo Ruffolo ${ }^{1}$; \\ Roberta dos Santos Toledo'; Renata Cristina Ferreira Dias ${ }^{1}$; \\ Italmar Teodorico Navarro²; Regina Mitsuka-Breganó2; Odilon Vidotto ${ }^{2}$; \\ Roberta Lemos Freire ${ }^{2 *}$
}

\begin{abstract}
The leishmaniasis are a group of globally widespread parasitic diseases caused by a protozoa of the genus Leishmania, the state of Paraná accounts for $98 \%$ of leishmaniasis human cases in southern Brazil and the dogs might serve as a sentinel of the risk of infection to humans in a given area. The aim of this work was to study the epidemiology of leishmaniasis in dogs residents in two different environments, they are: recycling of solid waste centers (Group 1) and a neighborhood adjacent to a forest (Group 2), both in Londrina, Paraná State, Brazil and to determine epidemiological variables associated to infection in these different realities. Serum samples, randomly collected, from 61 dogs from Group 1 and from 74 dogs from Group 2 were submitted to Indirect Immunofluorescence Antibody Test (IFAT) to research for anti-Leishmania IgG antibodies. Of the 135 dogs analyzed, 13 animals $(9.6 \%)$ were positive; nine (14.7\%) in Group 1 and four (5.4\%) in Group 2, the difference between the groups is not statistically significant. These results suggest the presence of the protozoan Leishmania spp. in both environments studied which indicate potential for infection in the human population.
\end{abstract}

Key words: Environment. Leishmaniasis. Marginality. Risk factors. Seroprevalence.

\section{Resumo}

As leishmanioses são um grupo de doenças parasitárias disseminadas por todo o mundo, causadas por protozoários do gênero Leishmania, o estado do Paraná é responsável por $98 \%$ dos casos de leishmaniose em humanos do Sul do Brasil e os cães podem servir como sentinelas para o risco de infecção em humanos em uma dada área. O objetivo desse trabalho foi estudar a epidemiologia da leishmaniose em cães residentes em dois diferentes ambientes, são eles: centros de reciclagem de resíduos sólidos (Grupo 1) e um bairro adjacente a uma floresta (Grupo 2) em Londrina/PR, Brasil e determiner variáveis epidemiológicas asociadas à infecção nessas diferentes realidades. Amostras de soro, randomicamente coletadas, de 61 cães do Grupo 1 e de 74 cães do Grupo 2 foram submetidos à Reação de Imunofluorescência Indireta (RIFI) para pesquisa de anticorpos IgG anti-Leishmania. Dos 135 cães analisados, $13(9,6 \%)$ foram positivos; $9(14,7 \%)$ no Grupo 1 e $4(5,4 \%)$ no Grupo 2, a

\footnotetext{
${ }^{1}$ Discentes, Universidade Estadual de Londrina, UEL, Londrina, PR, Brasil. E-mail: leticosta@gmail.com; eloiza.vet@gmail. com; brunoruffolo@ig.com.br; betatoledo@yahoo.com.br; rcfdias14@gmail.com

2 Profs. Drs., Departamento de Medicina Veterinária, CCA/UEL, Londrina, PR, Brasil. E-mail: italmar@uel.br; rbregano@uel.br; vidotto@uel.br; rlfreire@uel.br

* Author for correspondence
} 
diferença entre os grupos não foi estatisticamente significante. Esses resultados sugerem a presença do protozoário Leishmania spp. nos dois ambientes estudados o que indica potencial de infecção na população humana.

Palavras-chave: Ambiente. Fatores de risco. Leishmaniose. Marginalidade. Soroprevalência.

\section{Introduction}

The infectious agents of Leishmaniasis belong to the genus Leishmania (Kinetoplastida: Trypanosomatidae), wich is composed by protozoas that infect multiple mammalian species (GRAMICCIA, 2011). In nature, all species of this genus are transmitted to the vertebrate host by the bite of bloodsucking females of several species of sand flies (Insecta, Diptera), popularly known as sandfly, birigui, hang tough, cangalhinha, among others, depending on the region (FORATTINI, 1973). Leishmania spp can lead to diseases with a wide spectrum of clinical signs, collectively known as leishmaniasis, which are zoonosis and neglected infectious diseases that affect twenty million people worldwide (DUJARDIN et al., 2008). Ten countries (Afghanistan, Algeria, Colombia, Brazil, Iran, Syria, Ethiopia, North Sudan, Costa Rica and Peru) together account for 70 to $75 \%$ of global estimated cutaneous leishmaniasis (CL) incidence (ALVAR et al., 2012).

The American Cutaneous Leishmaniasis (ACL) in Brazil represents a serious public health problem because it has been diagnosed in all constituent states and in cases with mucosal involvement, injuries can lead to social stigma (BRASIL, 2007). The state of Paraná accounts for $98 \%$ of Leishmaniasis human cases in southern Brazil (PONTELLO JUNIOR et al., 2013) and autochthonous cases of ACL have been reported in the Vale do Ribeira, Central, and Northern regions of Paraná State (CASTRO et al., 2007). According to Dantas-Torres et al. (2010), there is still speculation concerning the role of dogs as important ACL reservoirs; however there is no doubt that dogs are good sentinels for disease distribution on the environment and that the primary reservoirs are small mammals, particularly wild rodents.

Leishmaniasis are dynamic diseases: transmission routes change based on environmental, demographic, and human behavioral factors that alter the range and density of vectors and reservoirs and increase the risk of human and animal exposure to infected phlebotomine sandflies (GRAMICCIA, 2011; DUJARDIN et al., 2008). Environmental impacts and anthropogenic actions to the environment, with social and economic changes, have allowed the vector to adapt to the peridomiciliary environment and spread disease. The production of huge quantities of waste, the dwindling areas available for disposal of these materials, the man entry into the wild due to the urbanization process are examples of human actions that occur in the city of Londrina/PR; creating environments conducive to the spread of Leishmaniasis. The aim of this work was to study the epidemiology of Leishmaniasis in dogs residents in two different environments, they are: recycling of solid waste centers (Group 1) and a neighborhood adjacent to a forest (Group 2), both in Londrina, Paraná State, Brazil and to determine epidemiological variables associated to infection in these different realities.

\section{Material and Methods}

\section{Ethical committee}

This study was approved by the Ethics and Animal Experimentation Committee of the Universidade Estadual de Londrina and obtained a favorable opinion ( $\mathrm{n}^{\circ} 57 / 2006$ and 69/2006) for execution of the work. 
Area of study

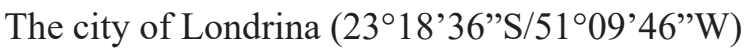
is located in the northern region of Paraná State, a North-central mesoregion of Paraná in southern Brazil. It lies $610 \mathrm{~m}$ above sea level and has a subtropical climate, with year-round rainfall concentrated mostly during the summer months. It has an average annual temperature above $21^{\circ} \mathrm{C}$ and an estimated human population of 510,707 (IBGE, 2009). Considering a relationship dog:man 1:4 we have estimated the dog total population in 127,677 dogs in the city.

\section{Sampling}

The number of dogs captured was calculated using the EpiInfo 3.5.3 (CDC, Atlanta). For a population of 128,000 dogs, a prevalence of $10 \%$ was estimated, precision of $5 \%$ and significance level of 5\%, resulting in 135 samples. The samples were collected of dogs from different collection sites, with two peculiar environmental characteristics, so two groups were formed.

Group 1: Composed of dogs inhabiting recycling centers of solid waste and junkyard of the five regions of the city of Londrina/PR (North, South, East, West and Central). Thirty seven sites were randomly selected whose starting point was the surroundings of Basic Health Units (BHU) in these regions. The blood of these dogs were collected in accordance with the permission of the owners along with the completion of an epidemiological questionnaire from September to December, 2006.

Group 2: Composed of dogs inhabiting Jardim Califórnia neighborhood, situated in the east of the city of Londrina in the vicinity of a forest (about $200 \mathrm{~m}$ ) belonging to Arthur Thomas Park. The park has a total area of $85,47 \mathrm{ha}$, is located in the urban limits, just $6 \mathrm{~km}$ from the center, and is characterized as an urban forest. The neighborhood has a public square that serves as a shelter for horses of carters. The data and blood samples from dogs were collected from March to June 2007 with the authorization of the owners in a total of 53 homes randomly selected.

\section{Blood collection from dogs}

Blood was collected by jugular or cephalic venipuncture, using disposable syringes and $25 \times 7$ needles, and stored at room temperature in test tubes without anticoagulant until complete clot retraction. The blood clot was centrifuged for 10 min at $1,000 \mathrm{~g}$ to separate the serum. The sera was stored in polyethylene microtubes of $1.5 \mathrm{~mL}$ and kept at $-15^{\circ} \mathrm{C}$.

\section{Serology}

Serum samples were analyzed by IFAT to determine the prevalence of IgG anti-Leishmania spp. antibodies according to Guimarães et al. (1974). Leishmania spp. IFAT slides were prepared using Leishmania Leishmania amazonensis promastigotes. Dog anti-IgG conjugates (FITCSigma) were standardized. Known positive and negative dog serum samples were included in all slides tested as controls. For positive serum samples, parasites displayed a bright-green peripheral stain and were considered positive serum samples positive at 1:40 or more (OLIVEIRA et al., 2008). Positive samples were serially diluted two-fold until they were no longer reactive.

\section{Research tools}

In order to obtain epidemiological data, an epidemiological questionnaire was used, containing variables concerning characteristics from the environment, sanitation, breed, age, gender, feeding habits, free street access and others. Statistical association of these variables was later made with the outcome. 


\section{Statistical analysis}

Data tabulation was performed using EpiInfo 3.5.3 (DEAN et al., 1990). Differences between proportions and statistical significance were evaluated by chi-square $\left(x^{2}\right)$ or Fisher's exact tests with a $5.0 \%$ significance level.

\section{Results}

A total of 135 dogs were analyzed for antibodies against Leishmania spp and 13 animals (9.6\%) were positive in the IFAT.

Considering the Group 1, 37 recycling solid waste points were studied, among these, 15 had homes, and 26 points stocked paper, paperboard, plastic, aluminum and in 18 main activity was the junkyard trade. Blood samples were collected from 61 dogs, most aged between one and eight years, 27 were males and 34 females. Of these 61 dogs, nine (14.7\%) were positive to IFAT: seven had title equal to 40 , one had title equal to 80 and one animal had title equals 320 .

With respect to Group 2, of the 53 homes visited in California neighborhood, 74 dogs were submitted for blood collection, 31 females and 43 males. The animals were between one and eight years of age. Of these 74 dogs, four $(5.4 \%)$ were positive to the IFAT: three animals had titers of 40 and one animal had title 80. Comparing Groups 1 and 2, there was no statistically significant difference $(\mathrm{p}=$ 0.123 ; $\mathrm{OR}=0.33 ; 95 \%$ CI 0.08 to 1.26 ), there was also no statistically significant difference between seropositivity in dogs and the variables studied in the epidemiological questionnaire.

\section{Discussion}

Other Leishmania spp. seroepidemiological studies in northern Paraná have shown prevalence to vary between $1.2 \%$ and $45.4 \%$ from 2007 to 2015 among dogs in urban environments. Zulpo et al. (2012) and Caldart et al. (2015) studied animals from Londrina and found 11.6\% (13/112) and $1.2 \%(3 / 236)$ of seropositivity using IFAT method with 1:40 as a cutoff, respectively; the low prevalence of $1.2 \%$ found by the authors may be explained because this study population consisted of clinically healthy animals undergoing elective castration surgery. Pittner et al. (2009), using both, IFAT and PCR, demonstrated $22.8 \%$ of positivity in domiciled dogs and $26.7 \%$ in stray dogs of Maringá municipality. Castro et al. (2007) studied several cities in the northern part of the state, including Londrina, and observed a prevalence of $18.4 \%$ (39/212) using ELISA, in contrast to IFAT used by the studies described above. Reis et al. (2011) evaluated urban dogs in Bela Vista do Paraíso, a city characterized by a considerably forested urban area, and found a prevalence of $45.4 \%$ (222/489) and $38.7 \%(189 / 489)$ by IFAT and ELISA, respectively. Castro et al. (2007) reported a 13.9\% (57/410) canine seropositivity rate in the three endemic regions of Paraná State. Constantino et al. (2014) found $6.81 \%(13 / 191)$ of seropositivity in dogs that were part of a castration campaign in the municipality of Telêmaco Borba using IFAT. Dias et al. (2013) studied domiciled dogs in Foz do Iguaçu and found $3.1 \%$ of seropositivity for leishmaniasis by IFAT.

Leishmania species isolated in humans and/ or animals in Paraná State are mainly L. Viannia braziliensis and in some cases $L$. (L.) amazonensis (CASTRO et al., 2007; PEREIRA, 2005, HOFFMANN et al., 2012). Several phlebotomine species are present in the same State, and the dominant vector species found infected is Nyssomyia whitmani (MEMBRIVE et al., 2004; OLIVEIRA et al., 2000) wich is involved in the transmission of $L$. (V.) braziliensis; however, $L$. (L.) amazonensis vectors have never been found in Paraná. Forattini (1973) affirmed that the ovoposition and the development of immature stages of mosquitoes occur in moist soil with the presence of organic matter, out of direct light. Due to the adaptation of sand flies to wild reservoirs of human environment, leishmaniasis transmission 
around the homes and households in the rural and urban area is favored and affects humans and domestic animals, especially dogs (LONARDONI et al., 1993, TEODORO et al., 1993). Dogs are good sentinels to human ACL cases; Londrina had 470 cases of human ACL confirmed and notified during the period of 1998 to 2009 , which is equivalent to 8.72 human cases per 100,000 inhabitants per year (PONTELLO JUNIOR et al., 2013).

There was no statistically significant difference $(p=0.123)$ between the dogs of groups 1 and 2 , although there was a higher percentage of reagents $(14.75 \%)$ in those areas of recycling of solid waste. Selective collection is a method that aims to minimize the waste of raw materials and recycling is the most rational way of managing municipal solid waste (MSW). According to the Companhia Municipal de Trânsito Urbano (CMTU) of Londrina, the composition of solid waste is $65 \%$ organic material and $35 \%$ of inorganic material (MORAES, 2003). However MSW contain several substances with high energy content and offer shelter and food for many living organisms, many of which use it as ecological niche, such as insects and rodents (LIMA, 1986), which act as vectors and reservoirs of various parasites. The recyclable material collection system is not operated only by associations, there are also the collectors of recyclable material, which operate independently and are not part of the official system (SOUZA, 2005). Even though the recycling of solid waste is a major source of income to the lowincome population, when held in a disorganized and informal manner, can expose the collectors to health risks (MEDEIROS et al., 2006). Bazo et al. (2011), studied collectors in Londrina/PR and found that the worker profile involved in this activity is women with low levels of education and remuneration; in relation to the work environment, adverse conditions to human health were found and a disagreeable odor also; in addition, none of recyclers makes use of safety equipment such as Personal Protective Equipment (PPE). According to Ferraz et al. (2012) collectors do not have any kind of support from governments, are at the mercy of their fate in case of acidentes or illness.

All the dogs of group 2 inhabited residences near the forest of Arthur Thomas Park (about 200m away) and a square that serves as a stop for carters; however, no significant difference $(p=0.616)$ as the greater or lesser distance of the residences of these sites was found. In a study realized by Oliveira et al. (2000) in Londrina Arthur Thomas Park, sandfly catches were made for two months, 4,266 sand flies were identified, the most frequent was N. whitmani $(39.26 \%)$, this study concluded that sand fly species has a large ability to adapt to manmade environment, playing an important role in the transmission of leishmaniasis in the studied area and in the vicinity. Castro et al. (2002), studied 332 human cases of ACL reported in the northern region of Paraná state and observed that waste and riparian forests or sporadic refugees between plantations favor the development of small foci of vectors, as there is moisture necessary for the development of sandflies, and the houses with positive people to leishmaniasis were found to $150-300 \mathrm{~m}$ of these locations. Silva-Filho et al. (2012) in a study with dogs from rural settlements in Northern Paraná, found that the presence of forest within $200 \mathrm{~m}$ of the house, the presence of organic matter (leaves) in the yard and the characteristic lesion of ACL, were statistically associated factors with Leishmaniasis. Constantino et al. (2014) have shown that Leishmania seropositivity was associated with the presence of stacked or composting leaves in the backyard and forest areas (squares, woods, parks) near the residence.

According to Chaves et al. (2008) studies of ACL and forest cover have ignored so far the multidimensionality of factors that shape patterns of infectious diseases and that landscape alone does not explain the spatial distribution of ACL. The author's analysis was performed with Costa Rica ACL cases from 1996 to 2000 and have demonstrated that living close to the forest was negatively associated with infection incidence once 
social marginality was evaluated as a key variable in explaining disease pattern. Their study shows that inequities, as measured by a marginalization index, may ultimately determine risk within that country, with socially excluded populations most affected by the disease. This study suggests control efforts targeted to socially excluded populations. In the present study dogs living close to the forest had lower seropositivity than dogs living in recycling centers, but the difference was not statistically significant.

According to Alvar et al. (2012), although Leishmaniasis is in ninth place among the most prevalent individual infectious diseases worldwide, it is largely ignored in the discussion of priorities for tropical diseases. The ACL has spread central urban and peri-urban areas due to the appearance of new outbreaks and the expansion of old foci, which may be a consequence of the absence or lack of systematic control over the insect vectors. According to the Secretaria de Saúde do Estado do Paraná, chemical control is indicated only in areas with transmission confirmation in peri- and/or intrahousehold (PARANÁ, 2010). Actions claiming control of wild and domestic reservoirs with ACL are not recommended and the treatment for this disease in animals is prohibited because we do not have specific drugs to use in animals in Brazil (BRASIL, 2009).

\section{Conclusions}

Our results suggest the presence of Leishmania spp. protozoan in the two different environments studied in Londrina, and indicate the potential for infection in the human population.

\section{References}

ALVAR, J.; VÉLEZ, I. D.; BERN, C.; HERRERO, M.; DESJEUX, P.; CANOS, J.; JANNIN, J.; BOER, M. den, the WHO Leishmaniasis control team. Leishmaniasis worldwide and global estimates of its incidence. PLoS one, San Francisco, v. 7, n. 5, e35671, 2012.
BAZO, M. L.; STURION, L.; PROBST, V. S. Caracterização do reciclador da ONG RRV em LondrinaParaná. Cadernos EBAPE.BR, Rio de Janeiro, v. 24, n. 4, p. 613-620, 2011.

BRASIL. Ministério da Saúde. Secretaria de Vigilância em Saúde. Manual de vigilância da leishmaniose tegumentar americana. 2. ed. Brasília: Ministério da Saúde, 2007. p. 58.

Orientações sobre condutas a serem adotadas frente ao descumprimento da portaria interministerial $\mathrm{n}^{\circ} 1426$ de 11 jul. 2009. Brasília: Advocacia Geral da União, 2009 (Paracer n 1243/2009).

CALDART, E. T.; CONSTANTINO, C.; PASQUALI, A. K. S.; BENITEZ, A. N.; HAMADA, F. N.; DIAS, R. C. F.; MATOS, A. R. N. de; MARANA, E. R. M.; NAVARRO, I. T.; MASCARENHAS, N. M. F.; FREITAS, J. C. de; FREIRE, R. L. Zoonosis in dogs and cats attended by the birth control project: Toxoplasma gondii, Leishmania spp. and Leptospira spp., serodiagnosis and epidemiology. Semina: Ciências Agrárias, Londrina, v. 36, n. 1, p. 253-266, 2015.

CASTRO, E. A.; THOMAZ-SOCCOL, V.; AUGUR, C.; LUZ, E. Leishmania (Viannia) braziliensis: Epidemiology of canine cutaneous leishmaniasis in the State of Paraná (Brazil). Experimental Parasitology, San Diego, v. 117, n. 1, p. 13-21, 2007.

CASTRO, E. A.; THOMAZ-SOCCOL, V.; MEMBRIVE, N.; LUZ, E. Estudo das características epidemiológicas e clínicas de 332 casos de leishmaniose tegumentar notificados na região norte do Estado do Paraná de 1993 a 1998. Revista da Sociedade Brasileira de Medicina Tropical, Uberaba, v. 35, n. 5, p. 445-452, 2002.

CHAVES, L. F.; COHEN, J. M.; PASCUAL, M.; WILSON, M. L. Exclusion modifies climate and deforestation impacts on a vector-borne disease. PLoS Neglected Tropical Diseases, San Francisco, n. 2, v. 2, e176, 2008.

CONSTANTINO, C.; PASQUALI, A. K. S.; CALDART, E. T.; FERREIRA, F. P.; MARANA, E. R. M.; FREIRE, R. L.; MITSUKA-BREGANÓ, R.; HILST, C. L. S.; VIDOTTO, O.; NAVARRO, I. T. Seroepidemiology of Leishmania spp. in dogs residing in Telêmaco Borba, Paraná, Brazil. Semina: Ciências Agrárias, Londrina, v. 35, n. 6, p. 3181-3190, 2014.

DANTAS-TORRES, F.; PAIVA-CAVALCANTI, M.; FIGUEREDO, L. A.; MELO, M. F.; SILVA, F. J. da; SILVA, A. L. da; ALMEIDA, E. L.; BRANDÃO-FILHO, S. P. Cutaneous and visceral leishmaniosis in dogs from a rural community in northeastern Brazil. Veterinary Parasitology, Amsterdam v. 170, n. 3-4, p. 313-317, 2010. 
DEAN, A. G.; DEAN, J. A.; BURTON, A. H.; DICKER, R. C. Epi info: a general-purpose microcomputer program for public health information systems. American Journal of Preventive Medicine, v. 7, n. 3, p. 178-182, 1990.

DIAS, R. C. F.; SOCCOL, V. T.; BISETTO-JÚNIOR, A.; POZZOLO, E. M.; CHIYO, L.; FREIRE, R. L.; MITSUKA-BREGANÓ, R.; PASQUALI, A. K. S.; ALBAN, S.; FENDRICH, R. C.; CALDART, E. T.; NAVARRO, I. T. Occurrence of anti-Leishmania spp. antibodies in domiciled dogs from the city of Foz do Iguaçu, State of Paraná, Brazil. In: WORLD CONGRESS ON LEISHMANIASIS, 5., 2013, Porto de Galinhas. Anais... Porto de Galinhas: Sociedade Brasileira de Medicina Tropical, maio 2013. p. 875-876.

DUJARDIN, J. C.; CAMPINO, L.; CAÑAVATE, C.; DEDET, J. P.; GRADONI, L.; SOTERIADOU, K.; MAZERIS, A.; OZBEL, Y.; BOELAERT, M. Spread of vector-borne diseases and neglect of leishmaniasis, Europe. Emerging Infectious Diseases, Atlanta, v. 14, n. 7, p. 1013-1018, 2008.

FERRAZ, L.; GOMES, M. H. A.; BUSATO, M. A. Catador de materiais recicláveis: um agente ambiental. Cadernos EBAPE.BR, Rio de Janeiro, v. 10, n. 3, p. 763768, 2012.

FORATTINI, O. P. Entomologia médica. São Paulo: Editora Edgar Blucher, 1973. v. 4, 658 p.

GRAMICCIA, M. Recent advances in leishmaniosis in pet animals: epidemiology, diagnostics and anti-vectorial prophylaxis. Veterinary Parasitology, Amsterdam, v. 181, n. 1, p. 23-30, 2011.

GUIMARÃES, M. C. S.; GIOVANNINI, V. L.; CAMARGO, M. E. Antigenic standardization from mucocutaneous leishmaniasis immunofluorescence test. Revista do Instituto de Medicina Tropical de São Paulo, São Paulo, v. 16, n. 1, p. 145-148, 1974.

HOFFMANN, A. R.; NAVARRO, I. T.; CAMARGOJUNIOR, V. E.; CALDART, E. T.; MITSUKABREGANÓ, R.; PEREIRA, P. M. Leishmania amazonensis em cão com quadro clínico de leishmaniose visceral no Estado do Paraná, Brasil - relato de caso. Semina: Ciências Agrárias, Londrina, v. 33, p. 32653270, 2012. Suplemento 2.

INSTITUTO BRASILEIRO DE GEOGRAFIA E ESTATÍSTICA - IBGE. Estimativas das populações residentes. Brasília: Editora Solução, 2009. Disponível em: $\quad<$ http://www.ibge.gov.br/home/estatistica/ populacao/estimativa2009/POP2009_DOU.pdf>. Acesso em: 10 nov. 2015.

LIMA, L. M. Q. Tratamento de lixo. São Paulo: Hemus Editora Ltda, 1986. 240 p.
LONARDONI, M. V. C.; TEODORO, U.; ARRAES, S. M. A. A.; SILVEIRA, T. G. V.; BERTOLINI, D. A.; ISHIKAWA, E. A. Y.; SHAW, J. J. Nota sobre leishmaniose canina no noroeste do estado do Paraná, Sul do Brasil. Revista de Saúde Pública, São Paulo, v. 27, n. 5, p. 378-379, 1993.

MEDEIROS, L. F. R.; MACEDO, K. B. Catador de material reciclável: uma profissão para além da sobrevivência? Psicologia \& Sociedade, Belo Horizonte, v. 18, n. 2, p. 62-71, 2006.

MEMBRIVE, N.A.; RODRIGUES, G.; LONARDONI, M. V. C.; SILVEIRA, T. G. V.; TEODORO, U. Flebotomíneos de municípios do norte do estado do Paraná, sul do Brasil. Entomologia y Vectores, Rio de Janeiro, v. 11, n. 4, p. 673-680, 2004.

MORAES, R. P. Resíduos sólidos e depósitos reembolsáveis - um estudo de caso para o município de Londrina - Paraná. 2003. Dissertação (Mestrado em Teoria Econômica) - Universidade de Brasília, Brasília.

OLIVEIRA, F. J. A.; COSTA, I. C.; NUNES, V.; OLIVEIRA, O.; OLIVEIRA NETO, B. P.; OLIVEIRA, J. E. Leishmaniose tegumentar americana: Flebotomíneos de área de transmissão do Parque Arthur Thomas na região de Londrina - PR. Biosaúde, Londrina, v. 2, n. 2, p. 81-87, 2000.

OLIVEIRA, T. M. F.; FURUTA, P. I.; CARVALHO, D. de; MACHADO, R. Z. A study of cross-reactivity in serum samples from dogs positive for Leishmania sp., Babesia canis and Ehrlichia canis in enzyme- linked immunosorbent assay and indirect fluorescent antibody test. Revista Brasileira de Parasitologia Veterinária, Jaboticabal, v. 17, n. 1, p. 7-11, 2008.

PARANÁ. Secretaria de Saúde, Vigilância Ambiental. In: Vetores (Leishmaniose). 3. ed. Brasília: [s.n.], jun. 2004, v. 2, p. 29. Disponível em: http://www.saude.pr.gov.br/ modules/conteudo/conteudo.php?conteudo=477. Acesso em: 6 fev. 2016.

PEREIRA, E. F. A. Variabilidade genética e diagnóstico molecular da Leishmania spp., pelas técnicas de RAPD e PCR, no Estado do Paraná e casos importados. 2005. Dissertação (Mestrado em Microbiologia, Parasitologia e Patologia) - Universidade Federal do Paraná, Curitiba.

PITTNER, E.; VOLTARELLI, E.; PERLES, T. F.; ARRAES, S. M. A. A.; SILVEIRA, T. G. V.; LONARDONI, M. V. C. Ocorrência de leishmaniose tegumentar em cães de área endêmica no Estado do Paraná. Arquivo Brasileiro de Medicina Veterinária e Zootecnia, Belo Horizonte, v. 61, n. 3, p. 561-565, 2009. 
PONTELLO JUNIOR, R.; GON, A. S.; OGAMA, A. American cutaneous leishmaniasis: epidemiological profile of patients treated in Londrina from 1998 to 2009. Anais Brasileiros de Dermatologia, Brasília, v. 88, n. 5, p. 748-53, 2013.

REIS, H. R.; LOPES-MORI, F. M. R.; REIS, C. R. dos; FREIRE, R. L.; MARANA, E. R. M.; CHRYSSAFIDIS, A. L.; TEDIM, A. V.; RUFFOLO, B. B.; BUGNI, F. M.; CASTRO, E. A. de; THOMAZ-SOCOL, V; NABUT, L. B.; NAVARRO, I T. Soroprevalência da leishmaniose tegumentar americana (LTA) canina e fauna de Flebotomíneos (Diptera: Psychodidae) em Bela Vista do Paraíso, Paraná. Semina: Ciências Agrárias, Londrina, v. 32, n. 3, p. 1083-1094, 2011.

SILVA-FILHO, M. F.; TAMEKUNI, K.; TOLEDO, R. S.; DIAS, R. C. F.; LOPES-MORI, F. M. R.; MITSUKABREGANÓ, R.; THOMAZ-SOCOL, V.; GARCIA, J. L.; FREIRE, R. L.; VIDOTTO, O.; NAVARRO, I. T. Infection by Toxoplasma gondii and Leishmania spp. in humans and dogs from rural settlements in Northern Paraná State, Brazil. Semina: Ciências Agrárias, Londrina, v. 32, p. 3251-3264, 2012. Supplement 2.
SOUZA, P. R. B. A parceria na coleta seletiva de Londrina sob a ótica da economia dos custos de transação: um estudo de caso. 2005. Dissertação (Mestrado em Administração) - Universidade Estadual de Maringá, Maringá.

TEODORO, U.; LA SALVIA FILHO, V.; LIMA, E. M.; SPINOSA, R. P.; BARBOSA, O. C.; FERREIRA, M. E. M. C.; SILVEIRA, T. G. V. Flebotomíneos em área de transmissão de leishmaniose tegumentar na região norte do Estado do Paraná - Brasil: variação sazonal e atividade noturna. Revista de Saúde Pública, São Paulo, v. 27, n. 3, p. 190-194, 1993.

ZULPO, D. L.; LEITE, J. H. A. de C.; CUNHA, I. A. L. da. Ocorrência de anticorpos contra Leishmania spp., Neospora caninum e Toxoplasma gondii em soros de cães atendidos no Hospital Veterinário da Universidade Estadual de Londrina - PR. Semina: Ciências Agrárias, Londrina, v. 33, n. 5, p. 1897-1906, 2012. 